\title{
Primary Repair of Femoral Pseudoaneurysm Secondary to Interventional Procedures
}

\section{Girişimsel Prosedürlere Bağlı Gelişen Femoral Psödoanevrizmanın Primer Onarımı}

\author{
Ali Cemal DÜZGÜN ${ }^{(1)}$, Ekin İLKELi் 2*
}

1 Cardiovascularsurgery, Ankara Training andResearchHospital, Ankara,Turkey.
2 Cardiovascularsurgery, Düzce StateHospital, Düzce,Turkey
* Corresponding Author:Ekin İLKELİ.E-mail:ekinilkeli@hotmail.com.

ÖZET

Amaç: Bu çalışmada iyatrojenik femoral psödoanevrizma tedavisinin kros-klemp konulmadan primer sutür tekniği ile onarımını, tecrübelerimizle paylaşmak istedik.

Materyal ve metot: Eylül 2015 ile ağustos 2020 tarihleri arasında femoral psödoanevrizma tanısı konulmuş 30 hasta çalışmaya dahil edildi. İyatrojenik olmayan anevrizmalar ve $4 \mathrm{~cm}$ den küçük anevrizmalar ile tromboze anevrizmalar çalışma dışı bırakıldı. Femoral anevrizmalar lokal yada genel olarak anestezi ile opere edildi. Tüm psödoanevrizmalarda tanı ultrasonografi ve bilgisayarlı tomografi ile konulmuştu.

Bulgular: Periferik arteriyel emboli $1(\% 4)$ hastada meydana geldi. Tüm femoral psödoanevrizmaların kross-klemp konmadan primer sutür tekniği ile onarımı gerçekleştirildi. Erken post operatif dönemde ölüm olmadi.

Sonuç: Femoral psödoanevrizmaların kros konulmadan primer sutür tekniği ile cerrahi tedavisinin iyi bir seçenek olarak değerlendiriyoruz.

Anahtar Kelimeler: İyatrojenik Hastalık, Anevrizma, Yalancı, Anjiyoplasti, Cerrahi, Femoral Arter.

Citation: Düzgün AC, İlkeli E. Primary repair of femoral pseudoaneurysm secondary to interventional procedures. Van Sag Bil Derg 2021, 14,(1) 93-97.

https://doi.org/10.52976/v ansaglik.847960.

Recieved date: 27/12/2020

Accepted date: 23/02/2021

Published date: 30/04/2021

\begin{abstract}
Objective: This study aimed to report our clinical experience with the treatment of iatrogenic femoral pseudoaneurysms with the primary suture technique.

Material and Method: Thirty patients treated with the diagnosis of femoral pseudoaneurysm in the femoral artery between September 2015 and August 2020 participated in the Non-iatrogenic pseudoaneurysms, iatrogenic aneurysms smaller than $4 \mathrm{~cm}$, and thrombosed aneurysms were excluded. All pseudoaneurysms were diagnosed by ultrasonography and computed tomography.

Results: Peripheral arterial thrombosis developed in 1 (4\%) patients. All femoral pseudoaneurysms were repaired with primary suture without clamping. No early postoperative deaths occurred.

Conclusion: We consider surgical treatment of femoral pseudoaneurysms with primary suture technique without cross-placing as a good option.
\end{abstract}

Keywords: Iatrogenic Disease, Aneurysms, False, Angioplasty, Surgery, Femoral Artery.

\section{INTRODUCTION}

Femoral pseudoaneurysm (FPA) is the most common complication of vascular arterial catheterization and occurs mostly in the femoral artery, which is used for diagnosis and invasive interventional procedures (Koza, 2020). Anticoagulant therapies, thrombocytopenia, vessel wall calcification, and atherosclerosis increase the risk of the pseudoaneurysm formation (Houlind, 2017).
Potential complications of these aneurysms include hemorrhage, thrombosis, peripheral embolism, dissection, the A-V fistula formation, and pressure on the surrounding tissues (Steinhubl, 2002).

Arterial examination with Doppler USG is considered as the gold standard in the diagnosis of pseudoaneurysms, with 100\% accuracy (Middleton, 2005). Pseudoaneurysms, which are smaller than 2 $\mathrm{cm}$, have a predisposition for spontaneous thrombosis, apart from patients using anticoagulants. 
USG-guided compression (UGC) may be effective for the majority of patients who do not receive anticoagulant therapy. Other options include USG-guided thrombin (UDTI) injection, coiled or covered stents, and endovascular interventions. Open surgical repair is considered as the best treatment option for patients with massive hematomas, skin necrosis, and the risk of rupture. Surgical exploration has been used as the standard treatment for false aneurysms. Nowadays, non-surgical and minimally invasive treatments have become available (Rashaideh, 2020).

However, cross-clamp surgery may not always be a good choice. Retrograde dissection, clamp injury and bleeding complications can sometimes be life-threatening. Therefore, primary surgical suture repair with finger control without cross-clamp is a good treatment modality in non-thrombosed femoral pseudoaneurysms.

Herein, we present a simple and effective technique without cross-clamp for FPA.

\section{MATERIAL and METHOD}

Thirty patients, who were treated with the diagnosis of FPA of the lower extremity artery between September 2015 and August 2020, took part in this study. Non-iatrogenic pseudoaneurysms, iatrogenic aneurysms smaller than $4 \mathrm{~cm}$ and thrombosed aneurysms were excluded. Data was retrospectively analyzed after obtaining the necessary ethical approval. (356/2020-03.09.2020- Ankara Eğitim Araştırma Hastanesi Etik Kurulu).

Data collected from patients records as demographic characteristics; age, sex, diagnosis, interventional procedure, sheath diameter, anesthesia procedure included in study. The anatomical localization and side of femoral pseudoaneurysms were determined from the records. The time between femoral artery puncture and aneurysm development was calculated.

All surgical procedures were performed by the same surgical team with regional or general anes- thesia. On supine position, and under local anesthesia with Marcaine 5\% plus Priloc 2\%, a vertical groin incision was made in the femoral artery trace. All operations were performed out without a cross-clamp. $1 \mathrm{cc}$ heparin was not administered because it was not crossed. Without placing vascular cross-clamps on the proximal and distal parts of the femoral artery, the bleeding in the femoral artery was controlled with a finger, and the lesion was primarily sutured with $5 / 0$ prolene suture.(Figure $1)$.

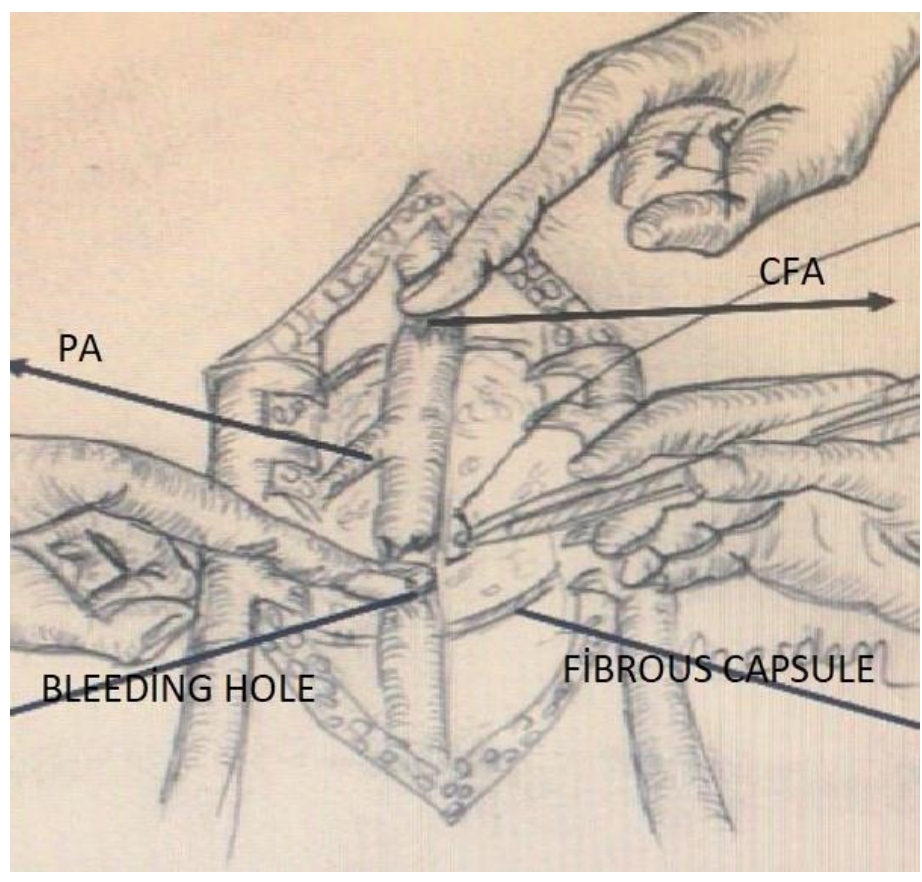

Figure 1.Illustration showing primary repair of femoral pseudoaneurysm

The diagnosis of femoral pseudoaneurysms was made using ultrasonography and computed tomography scan when deemed necessary. All patients were followed up with control ultrasonography for 3 months postoperatively. This scientific article was based on the Declaration of Helsinki.

\section{Data analysis:}

Patient's data were evaluated by using software SPSS 22 (IBM Corp, Armonk, NY, USA) program. Descriptive analyses were presented using means and standard deviations for normally distributed 
variables. Frequencies and percentages were given for categorical and nominal variables.

\section{RESULTS}

Of 30 patients who underwent pseudoaneurysm surgery, $40 \% \quad(n=12)$ were male and $60 \% \quad(n=18)$ were female. The mean \pm SD age was 74.03 (range 45-82) years. The interval between the femoral arterial puncture in the catheterization laboratory and the diagnosis of pseudoaneurysm was between 3 and 14 days (mean: 6.4). Surgical procedures were performed under local anesthesia in 21 (70\%) patients and under general anesthesia in $9(30 \%)$ patients who were diagnosed with the femoral pseudoaneurysm. The characteristics of the patients and the results are shown in table 1 . Coronary artery disease (CAD) has been the most common indication for femoral artery puncture. There was no significant correlation between $6 \mathrm{~F}$ and $7 \mathrm{~F}$ sheath diameters and pseudoaneurysm formation. Aneurysm formation occurred in only 3 patients after superficial femoral artery puncture.(Table 2)

Peripheral arterial thrombosis was developed in 1 (4\%) patient. All femoral pseudoaneurysms were repaired with primary suture without clamping. No early postoperative deaths occurred.

Postoperative 30-day observations were made. No major or minor vascular event was observed.

Table 1. Femoral pseudoaneurysms: patient characteristics, diagnosis and procedures

\begin{tabular}{|c|c|c|}
\hline Patient results & No (n) & Percent (\%) \\
\hline Age, mean (years) Mean $\pm S D: 74.03$ & & \\
\hline \multicolumn{3}{|l|}{ Sex } \\
\hline Male & 12 & 40 \\
\hline Female & 18 & 60 \\
\hline \multicolumn{3}{|l|}{ Diagnosis } \\
\hline CAD & 21 & 70 \\
\hline MI & 2 & 6 \\
\hline AI & 1 & 4 \\
\hline ASD & 1 & 4 \\
\hline MS & 3 & 10 \\
\hline AS & 2 & 6 \\
\hline \multicolumn{3}{|l|}{ İnterventional procedure } \\
\hline CAG & 9 & 30 \\
\hline PTCA & 9 & 30 \\
\hline STENT & 12 & 40 \\
\hline Sheath Diameter & & \\
\hline $6 \mathrm{~F}$ & 12 & 40 \\
\hline $7 F$ & 18 & 60 \\
\hline \multicolumn{3}{|l|}{ Aneshtesia Procedure } \\
\hline Local & 21 & 70 \\
\hline General & 9 & 30 \\
\hline
\end{tabular}

CAD: Coronary artery disease, MI: Mitral insufficiency, MS: Mitral stenosis, AI:Aortic insufficiency, AS:Aortic stenosis, ASD:Artial septal defect, CAG:Coronary angiography, PTCA:Percutaneous transluminal coronary angioplasty 
Table 2.Anatomical location femoral pseudoaneurysm

\begin{tabular}{cll}
\hline & No (n) & Percent (\%) \\
\hline $\begin{array}{c}\text { Side of the pseudoaneurysm } \\
\text { Right }\end{array}$ & 18 & 60 \\
Left & 12 & 40 \\
Localization of pseudoaneurysm & & \\
CFA & 27 & 90 \\
SFA & 3 & 10 \\
\hline \hline
\end{tabular}

\section{DISCUSSION}

Iatrogenic femoral pseudoaneurysm (FPA) occurs after an arterial puncture that causes blood to form a pulsatile mass in surrounding tissues. Unlike the progression of FPAs after surgery or trauma, $80 \%$ of cases of pseudoaneurysm caused by arterial perforation resolve spontaneously (Hashemi, 2010). The incidence of the formation of pseudoaneurysm after arterial puncture has been reported in literature as being between $0.2 \%$ and $6 \%$ (Gorecka, 2020).

Non-pulsatile, pseudoaneurysms of less than $4 \mathrm{~cm}$ and suitable anatomy are the first step in non-surgical treatment options. Ultrasound-guided compressions, percutaneous thrombin injection, embolization with coils or adhesives are available. Surgical treatment is mostly applied for complex cases. Surgical treatment requires skin incision, arterectomy, cross-clamping and bleeding control. Proximal and distal cross-clamping of the femoral artery always involves some potential risks.

In 30 patients, we were able to primary suture the femoral pseudoaneurysm without using a cross-clamp. This technique can be successfully administered to patients under local or general anesthesia. This helps less dissection, reduce overall surgery time, and can potentially prevent nearby nerve or vessel damage, preventing cross-clamp damage.

The results suggest that it may be a trigger for endothelial damage following vascular clamping.
Simultaneous pressure and cross-clamping is a cause of further injury and complications in common, superficial and profunda arteries. Therefore, instead of a harmful cross clamp on the vessel wall in aneurysms that are not always too large; and with surgical exposure and finger control, the pressure of the proximal artery provides adequate repair opportunity. In 30 cases, we only controlled the proximal common femoral artery with finger pressure, and we were able to suture the puncture site primarily.

Surgical treatment continues to be the gold standard in large and complicated aneurysms. Ultrasound-guided compression, percutaneous thrombin injection, embolization with coils or adhesives may not always be a treatment option (Babin-Ebell,2008). Reported $4.4 \%$ mortality in the surgical treatment of iatrogenic femoral artery pseudoaneurysms (Borioni et al., 2008). They reported the rate of bleeding as a complication of $13 \%$ and the rate of wound infection development as $6.5 \%$ in iatrogenic femoral artery pseudoaneurysm surgery (Piffaretti et al., 2011). No mortality was found in our study. Peripheral arterial thrombosis was formed by $1(4 \%)$. No major or minor vascular events were seen during the postoperative 30-day follow-up. If you do not have these options, it is useful to remember the option of making the surgical intervention minimal and without cross clamp. This surgical intervention without cross clamp protects the vascular wall from 
damage and also protects from distal embolism due to excessive manipulation. Distal embolization of plaque or thrombus via surgeon may cause limb ischemia following vascular interventions. This leads to the development of a second iatrogenic event and complications.

Massive hemorrhage resulting from rupture of the branch artery deriving from uterine artery has been reported to trigger a large retroperitoneal hematoma after femoral artery puncture (Liu, 2017). Our surgical strategy consisted of performing proximal and distal vascular control of the common femoral artery, primarily suture of the artery aneurysm. The patients were discharged after a 2-day post-surgical stay, with a good evolution without complications.

A limitation in our report is the limited number of patients. The analysis is relevant as it has been done single-centered, so it is not sufficient for generalization.

As a result; it is beneficial to use the primary suture technique in suitable patients after a thorough examination of the arterial anatomy, the location and size of the aneurysm, the length and diameter of the aneurysm neck.

\section{Conflicts of Interest}

The authors declare that there is no conflict of interest.

\section{REFERENCES}

Babin-Ebell J, Gimpel-Henning K, Sievers H-H, Scharfschwerdt M. Influence of clamp duration and pressure on endothelial damage in aortic cross-clamping. Interact Cardiovasc Thorac Surg 2009;10:168-71.

Borioni R, Garofalo M, De Paulis R, Albano P, Caprara E, Fratticci L, Chiariello L. Surgical treatment of femoral artery pseudoaneurysms after cardiac catheterization. Minerva Chir 2008;63:277-82.
Gorecka J, Chen JF, Shah S, Dardik A, Guzman RJ, Nassiri N. A hybrid approach for vascular control and repair of an expanding iatrogenic femoral artery pseudoaneurysm. J Vasc Surg Cases Innov Tech 2020;6(3):460-3.

Hashemi Fard O. Iatrogenic femoral artery pseudoaneurysm (REVIEW OF TREATMENT OPTIONS). ARYA Atheroscler 2010;6(2):74-7.

Houlind K, Jepsen JM, Saicu C, Vammen S, Christensen JK, Ravn H. Current management of inguinal false aneurysms. J Cardiovasc Surg (Torino) 2017;58:278-83.

Koza Y, Kaya U. Retrospective Analysis of 120 cases of iatrogenic and traumatic peripheral arterial pseudoaneurysms. Eurasian J Med 2020;52(2):180-4.

Liu S-Y, Zeng B, Deng J-B. Massive retroperitoneal hemorrhage secondary to femoral artery puncture: A case report and review of literature. Medicine (Baltimore) 2017;96(50):e8724.

Middleton WD, Dasyam A, Teefey SA. Diagnosis and treatment of iatrogenic femoral artery pseudoaneurysms. Ultrasound Q 2005; 21(1):3-17.

Piffaretti G, Mariscalco G, Tozzi M, Rivolta N, Castelli P, Sala A. Predictive factors of complications after surgical repair of iatrogenic femoral pseudoaneurysms. World J Surg 2011;35:911-6.

Rashaideh MA, Janho KE, Shawaqfeh JS, Ajarmeh E, As'ad M. Ultrasound-guided thrombin injection versus ultrasound-guided compression therapy of iatrogenic femoral false aneurysms: Single center experience. Med J Armed Forces India 2020;76(3):293-7.

Steinhubl SR, Berger PB, Mann JT, Fry ETA, DeLago A, Wilmer $\mathrm{C}$ et al. Early and sustained dual oral antiplatelet therapy following percutaneous coronary intervention: a randomized controlled trial. JAMA 2002;288(19):2411-20. 